\title{
Antimicrobial activity of Anacardium occidentale L. leaves and barks extracts on pathogenic bacteria
}

\author{
Chabi Sika K. ${ }^{1}$, Sina H. ${ }^{1}$, Adoukonou-Sagbadja H. ${ }^{2}$, Ahoton L. E. ${ }^{3}$, Roko G. O. ${ }^{1}$, Saidou A. \\ Adéoti K. ${ }^{5}$, Ahanchede A. ${ }^{3}$ and Baba-Moussa L. ${ }^{{ }^{*}}$ \\ ${ }^{1}$ Laboratoire de Biologie et de Typage Moléculaire en Microbiologie, Faculté des Sciences et Techniques, Université \\ d'Abomey-Calavi, Bénin. \\ ${ }^{2}$ Laboratoire des Ressources Génétiques \& Amélioration des Espèces, Faculté des Sciences et Techniques, Université \\ d'Abomey-Calavi, Bénin. \\ ${ }^{3}$ Laboratoire de Biologie Végétale, Faculté des Sciences Agronomiques, Université d'Abomey-Calavi, Bénin. \\ ${ }^{4}$ Laboratoire des Sciences du Sol, Faculté des Sciences Agronomiques, Université d'Abomey-Calavi, Bénin. \\ ${ }^{5}$ Laboratoire de Microbiologie et de Technologie Alimentaire, Université d'Abomey-Calavi, Bénin.
}

Received 26 April, 2014; Accepted 26 May, 2014

\begin{abstract}
The aim of this study was to investigate the antibacterial activity of aqueous, ethanol, ethyl acetate and dichloromethane extracts of two different cashew tree parts (leaf and bark). The susceptibility of strains to the different extracts was evaluated in vitro by disc diffusion method on ten reference strains and nine foods strains. The minimum inhibitory concentrations (MIC) and minimum bactericidal concentrations (MBC) were determined respectively by macro-dilution method and seeding on solid medium. Among the four types of extracts, only the ethanol and ethyl acetate extracts of the two organs inhibited the growth of both bacteria and yeast. The MIC varies respectively between 0.039 and 0.625 $\mathrm{mg} / \mathrm{ml}$ for reference strains and from 0.078 to $2.5 \mathrm{mg} / \mathrm{ml}$ for food isolated strains. Concerning MBC, it varies from 0.313 to $20 \mathrm{mg} / \mathrm{ml}$ for food isolated strains and from 0.078 to $20 \mathrm{mg} / \mathrm{ml}$ for reference strains. The ethanol and acetyl acetate extracts of the two cashew organs displays both a bacteriostatic and bactericidal effects on tested microorganisms. Our results suggest that extracts from cashew leaves may provide novel precursors for antimicrobial drug development research.
\end{abstract}

Key words: Antibacterial activity, Anacardium occidentale L., Staphylococcus, Benin.

\section{INTRODUCTION}

African flora in general and Benin in particular, have an important reserve of aromatic, food and medicinal plants. It was demonstrated that medicinal plants play an important role in the African pharmacopoeia (Badiaga,
2011). Indeed, according to WHO (2002), about $80 \%$ of Africans have recourse to traditional medicine that involves the use of plants' active principles, to treat most of diseases. Thus, a medicinal plant is defined as all plant

\footnotetext{
${ }^{*}$ Corresponding author. E-mail: laminesaid@yahoo.fr.
} 
that one or more of its part including a substance can be used for therapeutic purposes or as a precursor of the synthetic antimicrobials (Sofowora,1984).

In Benin, several ethnobotanical studies have focused on identifying medicinal plants species (Sopkon and Ouinsavi, 2002; Biecke, 2004, etc.). Among these plant species, Anacardium occidentale L. has an important place. Its leaves, bark, roots and stem are traditionally used for the treatment of numerous diseases such as, allergy, cough, stomach ache, diarrhea, skin infections, etc. (Chabi Sika et al., 2013). Besides these medicinal uses, cashew plays several other important roles. Its wood is used mainly in carpentry, as firewood or turned into charcoal (Akinwale, 2000) whereas the resins are used in the manufacture of plastics and natural insecticides (Cavalcante et al., 2003).

In contrast to conventional medicine which seeks the origin and causes of diseases and infections, traditional medicine goes directly to the illness. The scientific study of the use of plants allows establishing a link between the two medicines and at term could eventually relieve populations (Badiaga, 2011). Nowadays, infectious diseases are responsible for $45 \%$ of deaths in lowincome countries and $50 \%$ of premature death worldwide (Gangoue, 2007). In addition, among the death caused by microorganisms, bacterial infections account for $70 \%$ of cases (Walsh, 2003). To control these pathogens, antibiotics are frequently used. Effective use of antibiotics in the control of pathogens has raised hopes for eradicating infectious diseases. Unfortunately, the emergence of antibiotic-resistant bacteria has put an end to this wave of optimism (Adejuwon et al., 2011).

To face this increasing inefficiency observed with available antibacterial, it is essential to seek new wide spectrum action substances with more effective action. For this kind of research, there are many options. Among the possible options, we can cite the exploration of natural resources which contains a numerous active substances (Bocanegra-Garcia et al., 2009). The aim of this work was to study the antibacterial activity of cashew barks and leaves on 10 reference strains and nine Staphylococcus species isolated from three meat products.

\section{MATERIALS AND METHODS}

\section{Tested microorganisms}

The microorganisms tested include both bacteria (Gram positive and negative) and yeast. These microorganisms are composed of ten (10) reference strains (Escherichia coli ATCC 25922, Staphylococcus aureus ATCC 29213, Staphylococcus epidermidis T22695, Pseudomonas aeruginosa ATCC 27853, Proteus mirabilus A24974, Micrococcus luteus, Proteus vulgaris A25015, Streptococcus oralis, Enterococcus faecalis ATCC 29212,Candida albicans MHMR) obtained from the National Laboratory for Quality Control of Medicines and Medical Consumables (LNCQ) and nine (9) species of Staphylococcus isolated from three different meat products in Ivory Coast (Attien et al., 2013).
Two parts (barks and leaves) of Anacardium occidentale L. were collected in plantations at Savè (Department Zou- Colline; Benin) in April 2013. After harvest, these parts are washed with clean water and then dried in the laboratory at room temperature $\left(25^{\circ} \mathrm{C}\right)$ for about two weeks. After drying, the plant samples were then ground with a Retschmachine (SM 2000/1430/Upm/Smf) grinding. The obtained powders were used for the further extractions.

\section{Preparation of extracts}

\section{Aqueous extracts}

The aqueous extracts were obtained by using an adaptation of the method developed by Guede-Guina et al. (1995). Briefly, $50 \mathrm{~g}$ of leaf or bark powder of $A$. occidentale obtained above was macerated in $500 \mathrm{ml}$ of distilled water on a magnetic agitator for 72 $\mathrm{h}$ at room temperature. The homogenate was then filtered two times on absorbent cotton and once on Whatman $\mathrm{N}^{\circ} 1$ paper. This filtrate was dried in the oven at $40^{\circ} \mathrm{C}$; the obtained powder is considered as the total aqueous extract ready to use for antimicrobial tests (Adebo et al., 2008).

\section{Ethanol, acetyl acetate and dichloromethane extracts}

For these extractions, the methodology used was an adaptation of the protocol described by Sanogo et al (2006) and N'Guessan et al. (2007). Briefly, $50 \mathrm{~g}$ of $A$. occidentale powders were macerated in $500 \mathrm{ml}$ of solvent ( $96 \%$ ethanol, ethyl acetate or dichloromethane) on magnetic agitator for $72 \mathrm{~h}$. After two successive filtrations on hydrophilic cotton and Wattman $\mathrm{N}^{\circ} 1$ paper, the filtrate was concentrated in a Rotavaporvacuum packed at $50^{\circ} \mathrm{C}$. After concentration, the filtrates were dried in an oven at $50^{\circ} \mathrm{C}$. After drying, the powders were stored in tightly sterile bottles at $4^{\circ} \mathrm{C}$ until used.

\section{Evaluation of the plant extracts'antibacterial activity}

\section{Sensitivity test}

The antibacterial activities of the different extracts obtained were determined by employing the agar diffusion method of Anani et al. (2000). Four to five sterile discs with $5 \mathrm{~mm}$ as diameter were lodged, under aseptic conditions, in a Petri dish previously flooded of the appropriate bacterial culture. The discs were aseptically impregnated with $30 \mu \mathrm{l}$ of the float of the crude plant extract stock solution, prepared $24 \mathrm{~h}$ before handling from $20 \mathrm{mg}$ crude extract dissolved in $1 \mathrm{ml}$ of sterile distilled water (SDW). The extracts were allowed to diffuse $(15-30 \mathrm{~mm})$ into the medium at room temperature and the plates were incubated at $37^{\circ} \mathrm{C}$ for $24 \mathrm{~h}$ (Adesokan et al., 2007). The zones of inhibition were measured using a scale (Doughari et al., 2007) after incubation time of 24 and $48 \mathrm{~h}$.

Determination of minimum inhibitory concentration (MIC) and minimal bactericidal concentration (MBC)

The minimum inhibitory concentrations of the plant extracts were determined using the tube dilution method test with visual assessment of growth of microorganisms (Delarras, 1998).

To achieve the range of concentrations, $1 \mathrm{ml}$ of plant extract of known concentration $(20 \mathrm{mg} / \mathrm{ml})$ was added to $1 \mathrm{ml}$ of the tube T1 SDW. After homogenization, $1 \mathrm{ml}$ of the mixture (sample + distilled water) was taken for the tube T1, for the tube T2. For the remaining range, $1 \mathrm{ml}$ of the mixture taken from the tube T2 was transferred into the tube T3. This procedure was repeated until T9 tube; $1 \mathrm{ml}$ of 


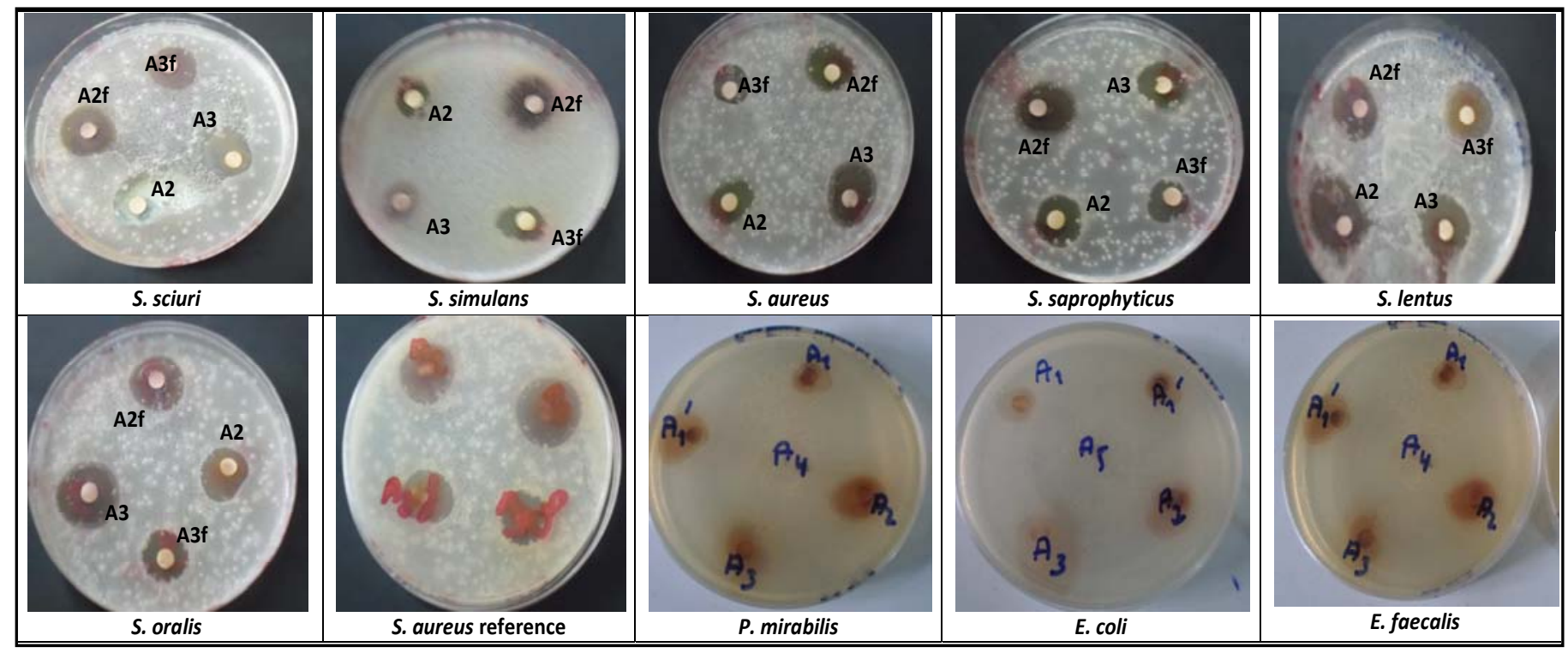

Figure 1. Sensitivity test realized on the reference and isolated food strains using the diffusion method. A1: aqueous bark extract, A2: ethanol bark extract, A3: acetyl acetate bark extract, A2f: ethanol leave extract, A3f: acetyl acetate leave extract, A4: dichloromethane bark extract, A1': control (ethanol), A5: control (acetyl acetate).

the content of this tube (T9) was rejected. Note that the control tube T0 receives only $1 \mathrm{ml}$ extract with the concentration of $20 \mathrm{mg} / \mathrm{ml}$.

The inoculum for each bacterial strain was made from a preculture. In brief, $1 \mathrm{ml}$ of the respective bacteria inoculum was added to experimental (T1 to T9) and control (T0 and T10) tubes. After 24 $h$ of incubation, the bacterial growth which leads to a turbidity was examined in each tube. The MICs of an extract against a given strain is the smallest concentration showing no visible growth on the naked eye.

The materials from each test tube used in the minimum inhibitory concentration assay that showed no growth after incubation, were streaked onto a solid nutrient agar plate and then incubated at $37^{\circ} \mathrm{C}$ for $24 \mathrm{~h}$. The lowest concentration of the extract that showed no growth on the plate after $24 \mathrm{~h}$ taken as the minimum bactericidal concentration (MBC) following Alade and Irobi (1993).

\section{Data analysis}

The data obtained were subjected to analysis of variance (ANOVA) using SAS 9.2 software. Duncan test is used to compare the average difference at a significance level of 0.05 .

\section{RESULTS}

\section{Antimicrobial activity of cashew's leaf and bark}

The results of sensitivity tests realized on the references strains and isolated food strains are summarized in Figure 1. By observing these results, it appears that the ethanol and acetyl acetate extracts have inhibited the growth of several microorganisms resulting in observation of the inhibition zone (Figure 1).The aqueous and dichloromethane extracts have no effect on the growth of studied strains. Thus, later on, only ethanol and acetyl acetate extracts will be used to determine susceptibility parameters.

Susceptibility of studied strains in the presence of ethanol and acetyl acetate extracts of cashew's leaves and backs

Figure 2 shows the antimicrobial activities of different cashew extracts on the reference and food strains. In total, $30 \%(3 / 10)$ of reference strains were sensitive to ethanol and acetyl acetate bark extracts. Considering the isolated food strains, they were sensitive respectively at $90(8 / 9)$ and $78 \%(7 / 9)$ for ethanol and acetyl acetate bark extracts. The isolated food strains were more sensitive to these two extracts than the reference strains. The same observations were made with ethanol and acetyl acetate extracts of the leaves with higher percentages. From these results, it is possible to conclude that extracts are more efficient on food isolates strains than on reference strains. Also, leaves extracts are more active than bark extracts independently of the origin of the strains.

\section{Susceptibility of reference strains in the presence of cashew's ethanol and acetyl acetate extracts}

The diameters of inhibition zones of the four extracts on the reference strains are shown in Figure 3. The susceptibility of reference strains varied depending on the type of extract but their effect was statistically different 


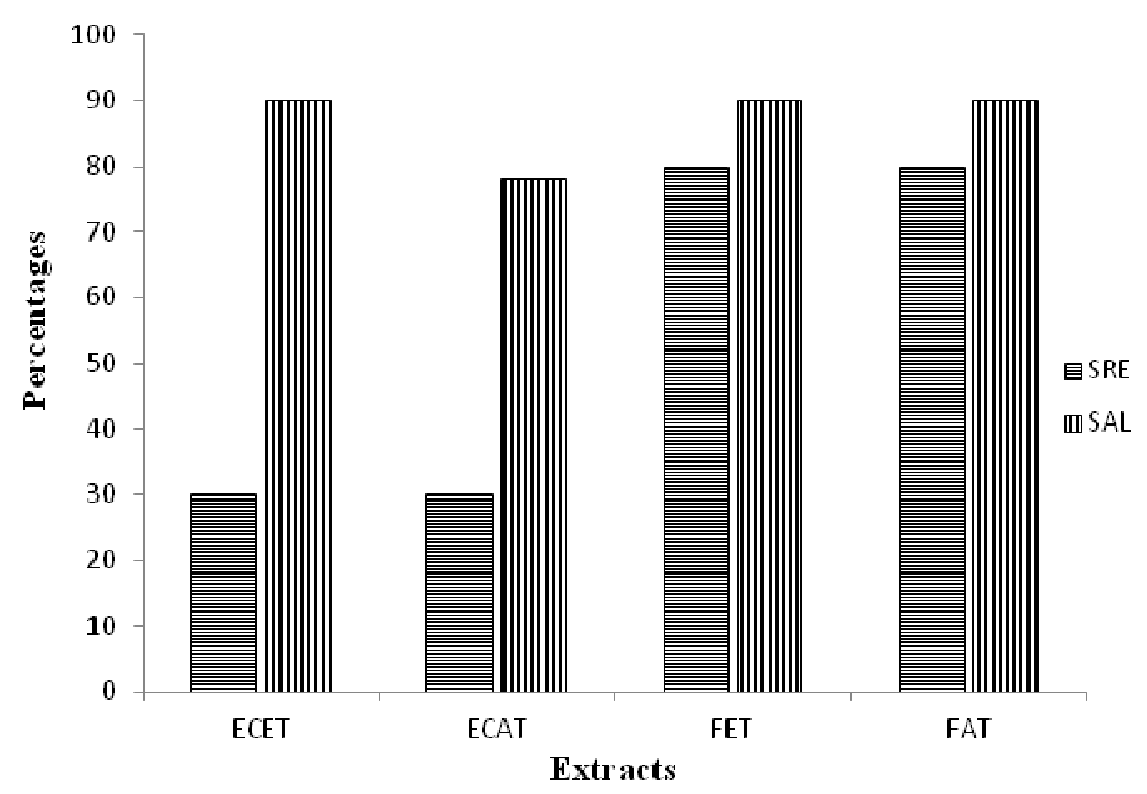

Figure 2. Antibacterial activity of different extracts from the leaves and bark of the cashew tree on reference and food strains. ECET: ethanol bark extract, ECAT: acetyl acetate bark extract, FET ethanol leaves extract, FAT: acetyl acetate leaves extract; SRE: reference strains and SAL: isolated food strains.

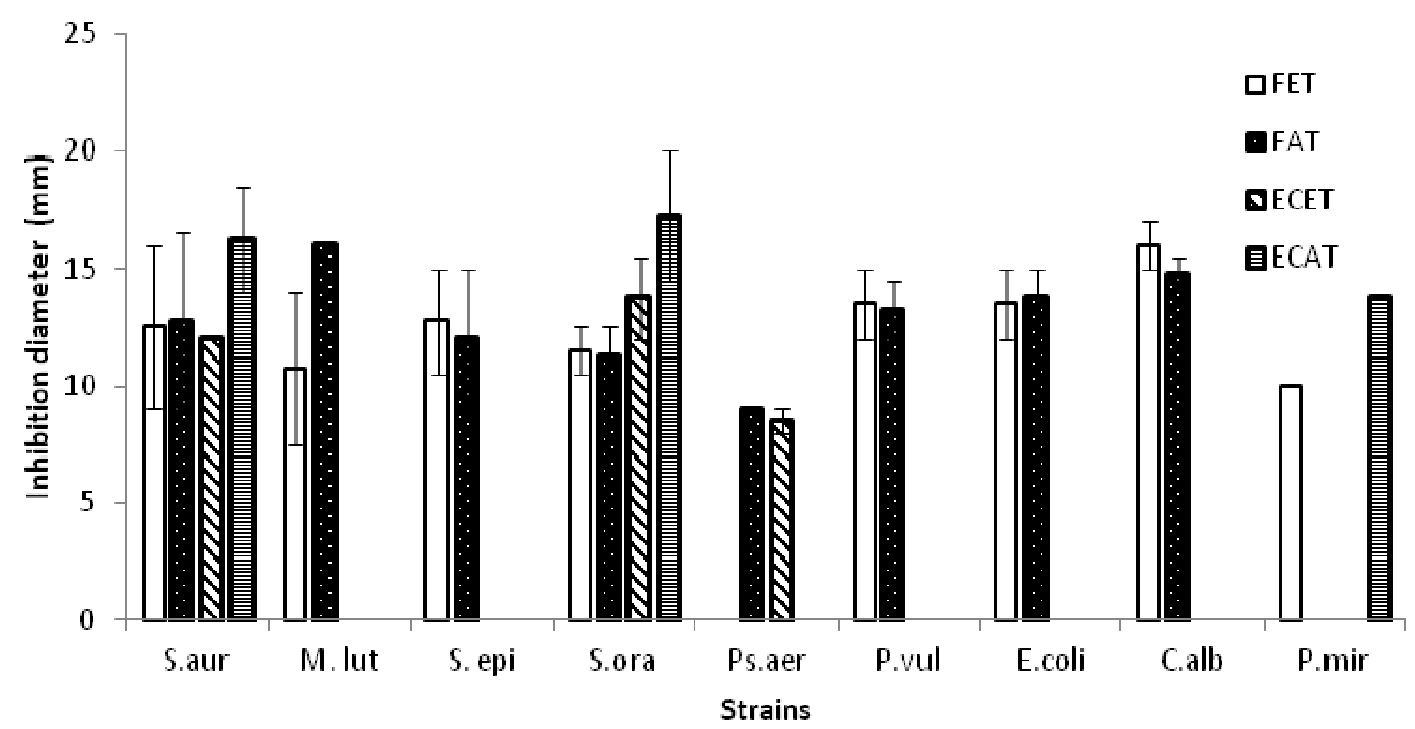

Figure 3. Mean inhibition zone diameter of some extracts in the reference strains. S. aur: Staphylococcus aureus, M.lut: Miccrococcus luteus, S. epi: Staphylococcus epidermidis, S. ora: Streptococcus oralis, Ps.aer: Pseudomanas aeruginosa, P.vul: Proteus vulgaris, E.coli: Escherichia coli, C.alb: Candida albicans, P.mir: Proteus mirabilis; ECT: ethanol bark extract, ECAT: acetyl acetate bark extract, FET ethanol leaves extract, FAT: acetyl acetate leaves extract.

$(p<0.05)$. Therefore, the result showed that $S$. aureus and $S$. oralis were sensitive to the four extracts and the largest diameters (16.25 and $17.5 \mathrm{~mm}$ ) were obtained with the acetyl acetate bark extract. With $S$. aureus, the three other extracts displayed approximately the same diameter $(12.5 \mathrm{~mm})$ whereas with $\mathrm{S}$. oralis, a difference was observed on the diameters of those extracts. Besides $P$. aeruginosa, sensitive only to acetyl acetate leaf extract and the ethanol bark extract, has the lowest inhibition diameter $(8.5 \mathrm{~mm})$ whereas $M$. luteus (only sensitive to extracts from leaves) has the largest inhibition diameter with acetyl acetate extract $(16 \mathrm{~mm})$. 

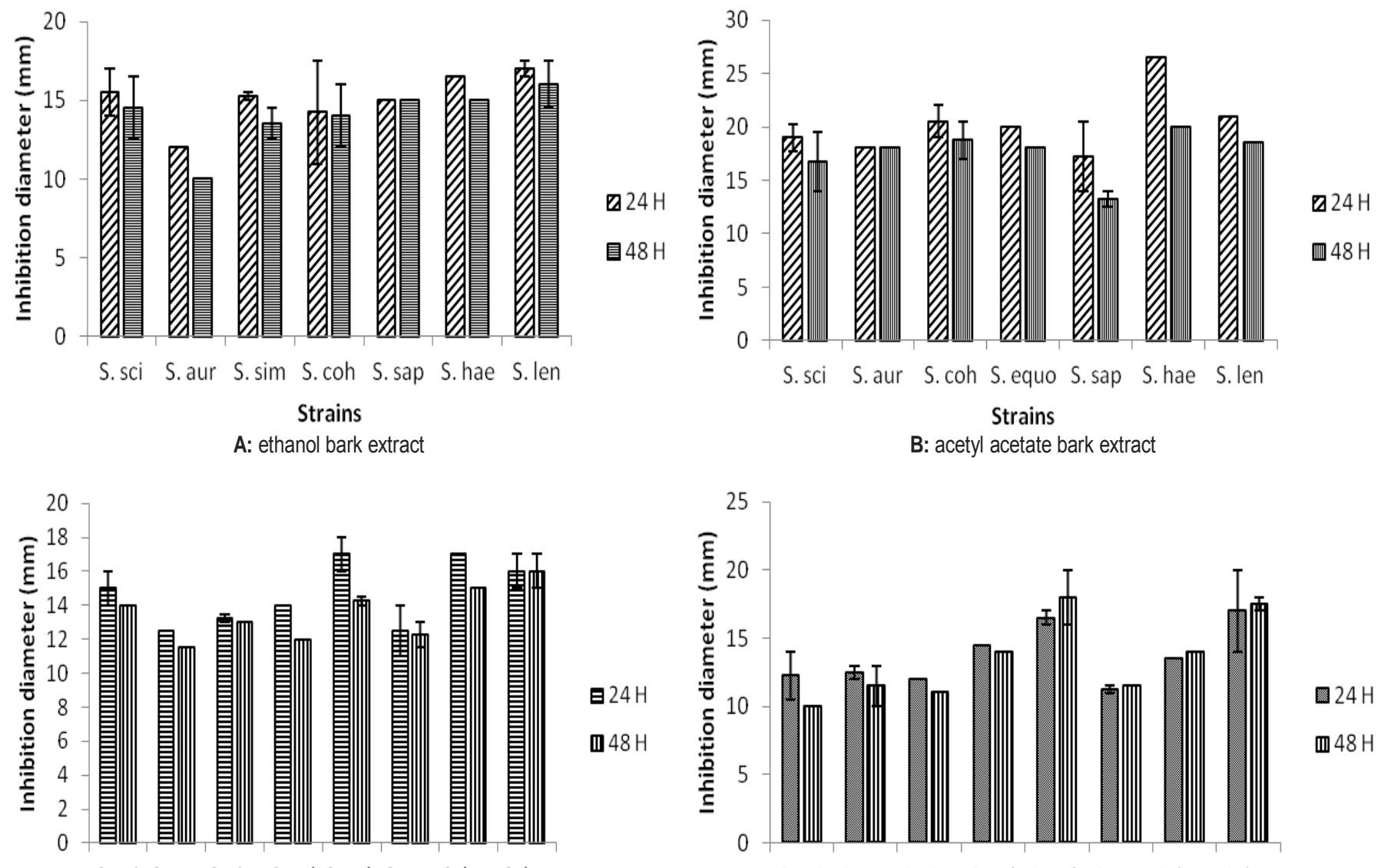

S. sci S. aur S. sim S. xyl S. coh S. sap S. hae S. len

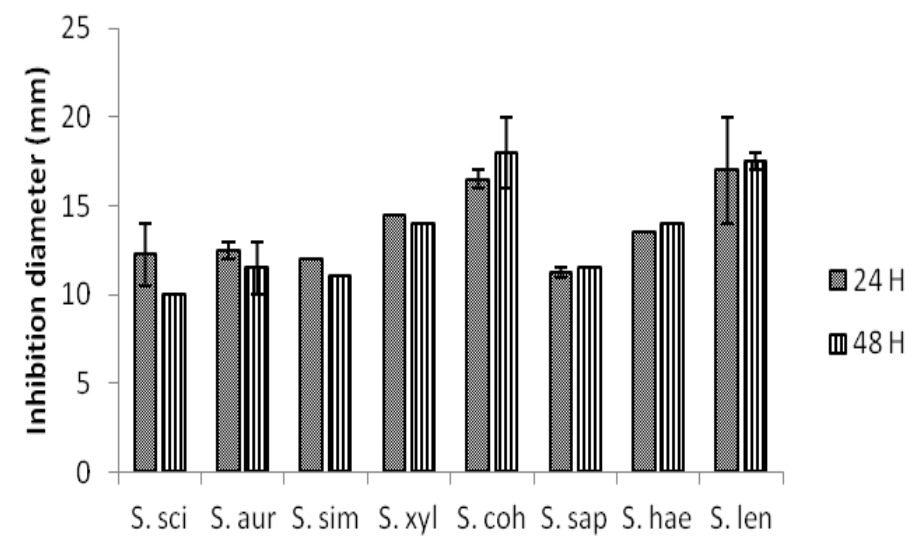

C: ethanol leaf extract

D: acetyl acetate leaf extract

Figure 4. Mean inhibition zone diameter of four extracts on isolated food strains during 24 and $48 \mathrm{~h}$ of incubation. S. sci: Staphylococcus sciuri; S. aur: Staphylococcus aureus; S. sim: Staphylococcus simulans; S. coh: Staphylococcus cohnii ; S. equo: Staphylococcus equorum; S. sap: Staphylococcus saprophyticus; S. hae: Staphylococcus haemolyticus; S. len: Staphylococcus lentus; S. xyl: Staphylococcus xylosus.

\section{Susceptibility of isolated food strains in the presence of cashew's ethanol and acetyl acetate extracts}

Figure 4 presents the mean inhibition diameters of different cashew extracts on food isolated strains during 24 and $48 \mathrm{~h}$ of incubation. The results revealed no significant difference $(p>0.05)$ between the inhibition diameters of the ethanol and acetyl acetate bark extracts whatever the incubation time ( 24 and $48 \mathrm{~h}$ ) on isolated food strains. Regarding the leaf extract, the inhibition diameters of the ethanol extract of the isolated food strains were significantly different between the strains $(p<$ $0.05)$ at $24 \mathrm{~h}$ and highly different $(p<0.001)$ after $48 \mathrm{~h}$. The inhibition diameters of acetyl acetate extract on food isolated strains were very different after $48 \mathrm{~h}$ but no statistical difference was observed at $24 \mathrm{~h}$. More other, the results show that these diameters were not statistically different $(p<0.05)$ over time $(24$ and $48 \mathrm{~h})$ regardless of the type of extract and the organ used.
From these results, it appears that inhibition diameters obtained after $24 \mathrm{~h}$ were higher than those measured after $48 \mathrm{~h}$. Unless the level of the ethanol extract (Figure $4 \mathrm{~A})$, S. saprophyticus strains had the same diameter at 24 and $48 \mathrm{~h}$ whereas with acetyl acetate extract the same diameters $(18 \mathrm{~mm})$ were obtained with $\mathrm{S}$. aureus. The larger diameters were obtained on S. lentus (17 and 16 $\mathrm{mm}$ ) at 24 and $48 \mathrm{~h}$ with the ethanol extract while with acetyl acetate extract the larger diameter ( 26.5 and 20 $\mathrm{mm}$ ) were obtained on S. haemolyticus.

Regarding leaf extracts (Figure 4C and D); it is observed that the inhibition diameters after $24 \mathrm{~h}$ were higher than those obtains after $48 \mathrm{~h}$ except for S. lentus that displayed the same inhibition diameters $(16 \mathrm{~mm})$ both at 24 and $48 \mathrm{~h}$ (Figure 4C). As shown in Figure 4D, it is observed that the mean of inhibition diameters at 24 $\mathrm{h}$ are higher than those obtained after $48 \mathrm{~h}$ with $\mathrm{S}$. sciuri, S. aureus, S. simulans and S. xylosus whereas with S. cohnii, S.saprophyticus, S. haemolyticus and S. lentus, 
Table 1. Minimum inhibitory concentrations of ethanol and acetyl acetate cashew' (bark; leaves) extracts on the reference strains.

\begin{tabular}{lcccc}
\hline \multirow{2}{*}{ Strains } & \multicolumn{4}{c}{ MIC $(\mathrm{mg} / \mathrm{ml})$} \\
\cline { 2 - 5 } & ECET & ECAT & FET & FAT \\
\hline S. aureus & 0.313 & 0.313 & 0.313 & 0.313 \\
M. luteus & - & - & 0.078 & 0.625 \\
S. epidermidis & - & - & 0.039 & 0.313 \\
S. oralis & 0.625 & 0.313 & 0.625 & 0.625 \\
E. faecalis & - & - & - & - \\
Ps. aeruginosa & 0.156 & - & - & 0.625 \\
P. mirabilis & - & 0.313 & 0.625 & - \\
P. vulgaris & - & - & 0.313 & 0.625 \\
E. coli & - & - & 0.625 & 1.25 \\
C. albicans & - & - & 0.156 & 0.313 \\
\hline
\end{tabular}

ECET: ethanol extract of the bark, ECAT: acetyl acetate bark extract, FET: ethanol extract of the leaves, FAT: acetyl acetate leaf extract.

the mean of inhibition diameters obtained after $48 \mathrm{~h}$ were higher than those measured at $24 \mathrm{~h}$.

Besides, it also appears from the results that $S$. sciuri, S. aureus, S. cohnii, S. saprophyticus and S. lentus are sensitive to the four extracts (Figure 4). For these 5 strains, the larger diameter was obtained with of acetyl acetate bark extract excepted for S. saprophyticus recording their largest inhibition diameter $(15 \mathrm{~mm})$ in the presence of ethanol bark extract. From these results, it appeared that $S$. aureus and S. haemolyticus displayed the same sensibility towards ethanol extracts of the two organs while for the acetyl acetate leaf extract, only $S$. haemolyticus have shown the highest diameters.

\section{Minimum inhibitory concentration (MIC) of cashew extracts on the reference strains}

Table 1 shows the minimum inhibitory concentrations (MIC) of cashew extracts (bark and leaf) on the reference strains. The computed MIC values ranged from 0.039 and $0.625 \mathrm{mg} / \mathrm{ml}$ for both cashew's leaf and bark depending on the strains. For acetyl acetate bark extract, the MIC was $0.313 \mathrm{mg} / \mathrm{ml}$ with three strains (S. aureus, $S$. oralis and $P$. mirabilis). Considering ethanol bark extract, the largest CMI was observed on S. oralis $(0.625$ $\mathrm{mg} / \mathrm{ml}$ ), while the most sensitive strain to this extract was $P S$. aeruginosa with $0.156 \mathrm{mg} / \mathrm{ml}$ as MIC.

For ethanol leaves extract, the highest MIC (0.625 $\mathrm{mg} / \mathrm{ml}$ ) was observed with $S$. oralis, $P$. mirabilis and $E$. coli while the lowest MIC $(0.039 \mathrm{mg} / \mathrm{ml})$ was observed on $S$. epidermidis. By testing the acetyl acetate leaf extract, the highest MIC obtained $(0.625 \mathrm{mg} / \mathrm{ml})$ was obtained on $M$. luteus, $S$. oralis, $P$. aeruginosa and $P$. vulgaris while the lowest MIC $(0.313 \mathrm{mg} / \mathrm{ml})$ was obtained with $S$.
Table 2. Minimum inhibitory concentrations of cashew bark and leave extracts on food strains.

\begin{tabular}{lcccc}
\hline \multirow{2}{*}{ Strains } & \multicolumn{4}{c}{ MIC $(\mathbf{m g} / \mathbf{m l})$} \\
\cline { 2 - 5 } & ECET & ECAT & FET & FAT \\
\hline S. sciuri & 0.313 & 1.25 & 1.25 & 1.25 \\
S. aureus & 0.313 & 0.313 & 0.625 & 1.25 \\
S. simulans & 2.5 & - & 2.5 & 2.5 \\
S. xylosus & 0.078 & - & 0.313 & 0.625 \\
S. cohnii & 0.156 & 0.313 & 1.25 & 1.25 \\
S. equorum & - & 0.078 & - & - \\
S. saprophyticus & 0.156 & 0.078 & 0.313 & 0.313 \\
S. haemolyticus & 0.313 & 0.313 & 0.625 & 0.625 \\
S. lentus & 0.313 & 0.078 & 1.25 & 1.25 \\
\hline
\end{tabular}

ECET: ethanol bark extract, ECAT: acetyl acetate bark extract, FET : ethanol leaves extract, FAT: acetyl acetate leaves extract.

aureus, S. epidermidis and C. albicans. The analysis of these results shows that $S$. aureus has the same MIC $(0.313 \mathrm{mg} / \mathrm{ml})$ for all the tested extracts.

\section{MIC of cashew extracts on food isolated strains}

Table 2 presents the MIC of cashew barks and leaves extracts on the isolated food strains. The results showed that the MIC varied according to strains and type of extracts (leaf and bark). MICs range from 0.078 to 2.5 $\mathrm{mg} / \mathrm{ml}$. Among tested strain, S. xylosus was more sensitive to the ethanol bark extract with a MIC of 0.078 $\mathrm{mg} / \mathrm{ml}$ while the least sensitive strain to this extract was S. simulans with a MIC of $2.5 \mathrm{mg} / \mathrm{ml}$. For acetyl acetate bark extract, the highest MIC $(1.25 \mathrm{mg} / \mathrm{ml})$ was obtained on S. sciuri while the lowest MIC $(0.078 \mathrm{mg} / \mathrm{ml})$ was obtained on S. equorum, S. saprophyticus and S. lentus.

With the ethanol leaf extract, the highest MIC $(2.5 \mathrm{mg} /$ $\mathrm{ml}$ ) was obtained on S. simulans while the lowest MIC $(0.313 \mathrm{mg} / \mathrm{ml})$ was obtained, with the same extract, on $S$. xylosus and S. saprophyticus. Using the acetyl acetate leaf extract, the highest MIC $(2.5 \mathrm{mg} / \mathrm{ml})$ was obtained on S. simulans while the lowest one $(0.313 \mathrm{mg} / \mathrm{ml})$ was obtained from $S$. saprophyticus. Finally, the results showed that $S$. haemolyticus has recorded the same MIC $(0.313 \mathrm{mg} / \mathrm{ml})$ with bark extracts. The same tendency was observed on the leaves extracts $(0.625 \mathrm{mg} / \mathrm{ml})$.

\section{Minimum bactericidal concentration (MBC) of cashew bark and leaf extracts on reference strains}

Table 3 presents the minimum bactericidal concentration (MBC) of cashew bark and leaf extract on reference strains. The results show that the MBCs varied according to the bacterial strains and organs used (bark and 
Table 3. Minimum bactericidal concentrations of cashew bark and leave extracts on reference strains.

\begin{tabular}{lcccc}
\hline \multirow{2}{*}{ Strains } & \multicolumn{4}{c}{ MBC $(\mathbf{m g} / \mathrm{ml})$} \\
\cline { 2 - 5 } & ECET & ECAT & FET & FAT \\
\hline S. aureus & 1.25 & 0.313 & 1.25 & 0.625 \\
M. luteus & - & - & 0.625 & 1.25 \\
S. epidermidis & - & - & 20 & 5 \\
S. oralis & 0.625 & 0.625 & 5 & 5 \\
E. faecalis & - & - & - & - \\
Ps. aeruginosa & 20 & - & - & 10 \\
$P$. mirabilis & - & 0.625 & 5 & - \\
$P$. vulgaris & - & - & 1.25 & 5 \\
E. coli & - & - & 10 & 10 \\
C. albicans & - & - & 0.313 & 0.625 \\
\hline
\end{tabular}

ECET: ethanol bark extract, ECAT: acetylacetate bark extract, FET: ethanol leave extract, FAT: acetylacetate leave extract.

Table 4. Minimum bactericidal concentrations of cashew bark and leaf extracts on food isolated strains.

\begin{tabular}{lcccc}
\hline \multirow{2}{*}{ Strains } & \multicolumn{4}{c}{ MBC $(\mathrm{mg} / \mathrm{ml})$} \\
\cline { 2 - 5 } & ECET & ECAT & FET & FAT \\
\hline S. sciuri & 10 & 10 & 10 & 20 \\
S. aureus & $>20$ & 20 & 10 & 10 \\
S. simulans & $>20$ & - & 5 & 10 \\
S. xylosus & $>20$ & - & 5 & 5 \\
S. cohnii & 1.25 & 0.625 & 5 & 2.5 \\
S. equorum & - & 0.625 & - & - \\
S. saprophyticus & 1.25 & 0.078 & 1.25 & 1.25 \\
S. haemolyticus & $>20$ & 20 & 5 & 5 \\
S. lentus & $>20$ & 20 & 20 & 10 \\
\hline
\end{tabular}

ECET: ethanol bark extract, ECAT: acetylacetate bark extract, FET: ethanol leave extract, FAT: acetylacetate leave extract.

leaves). Thus, the MBC varied from 0.313 to $20 \mathrm{mg} / \mathrm{ml}$. With the barks,S. oralis displayed the lowest MBC $(0.625$ $\mathrm{mg} / \mathrm{ml}$ ) in the presence of the ethanol extract and the largest MBC $(20 \mathrm{mg} / \mathrm{ml})$ was obtained with the same extract on $P$. aeruginosa. With acetyl acetate extract, $S$. aureus was the strain that displayed the lowest MBC $(0.313 \mathrm{mg} / \mathrm{ml})$ whereas the largest MBC $(0.625 \mathrm{mg} / \mathrm{ml})$ was obtained on $S$. oralis and $P$. mirabilis.

With leaf extract, the highest sensitivity was observed on Candida albicans using the ethanol extract displaying a MBC of $0.313 \mathrm{mg} / \mathrm{ml}$ while the highest MBC obtained with this extract was $20 \mathrm{mg} / \mathrm{ml}$ on S. epidermidis. For the acetyl acetate leaf extract, S. aureus and C. albicans showed the lowest MBC $(0.625 \mathrm{mg} / \mathrm{ml})$ while the highest
MBC $(10 \mathrm{mg} / \mathrm{ml})$ was obtained on $P$. aeruginosa and $E$. coli. Considering the CMB results, it appeared that $S$. oralis was more sensitive to both bark $(0.625 \mathrm{mg} / \mathrm{ml})$ and leaf $(5 \mathrm{mg} / \mathrm{ml})$ extracts.

\section{MBC of cashew bark and leaves extracts on food isolated strains}

Table 4 presents the minimum bactericidal concentrations of cashew' bark and leaf extracts on food isolated Staphylococcus strains. These results show that the MBC of the bark and leaf extracts varied from 0.078 to $20 \mathrm{mg} / \mathrm{ml}$ depending to the Staphylococcus species tested.

Using barks, the highest observed MBC $(10 \mathrm{mg} / \mathrm{ml})$ was obtained with the ethanol extract on $\mathrm{S}$. sciuri while the lowest MBC $(1.25 \mathrm{mg} / \mathrm{ml})$ was obtained with this extract on S. cohnii and S. saprophyticus. Indeed, with 20 $\mathrm{mg} / \mathrm{ml}$; the ethanol extract had no bactericidal effect on $S$. aureus, S. simulans, S. xylosus, S. haemolyticus and S. lentus. The acetyl acetate bark extract gives the largest MBC $(20 \mathrm{mg} / \mathrm{ml})$ with $S$. aureus, $S$. haemolyticus and $S$. lentus while the lowest MBC $(0.078 \mathrm{mg} / \mathrm{ml})$ was obtained on S. saprophyticus.

With the leaves, the largest MBC $(20 \mathrm{mg} / \mathrm{ml})$ was obtained on S. lentus (with ethanol extract) and S. sciuri (with acetyl acetate extract). The lowest MBC (1.25 $\mathrm{mg} / \mathrm{ml}$ ) was obtained on S. saprophyticus independently to the extract. From these results, it appears that $S$. cohnii was more sensitive to the acetyl acetate extract than the ethanol extracts independently to the organ used.

\section{Evaluation of bactericidal and bacteriostatical effects of cashew barkand leaves extracts}

To evaluate the effect of two types of the cashew bark and leaves extract on the reference and food isolated strains, the ratio of $\mathrm{MIC}$ and $\mathrm{MBC}$ parameters were calculated.The observation of these results allows concluding that these extracts have both bactericidal and bacteria-statical effects on reference and food-isolated strains. However, it was observed that the ethanol bark extract had no bactericidal effect on food-isolated strains (Tables 5 and 6).

\section{DISCUSSION}

In this study, four extract (aqueous, ethanol, acetyl acetate and dichloromethane) of leaf and back were tested on 19 strains. The ethanol and acetyl acetate extracts of the two organs have inhibited the growth of several microorganisms while dichloromethane and aqueous extracts have no effect on the strains tested at the dose of $20 \mathrm{mg} / \mathrm{ml}$. The ethanol and acetyl acetate 
Table 5. Bactericidal and bacteria-static effects of cashews bark and leaf extracts on reference strains.

\begin{tabular}{lcccc}
\hline \multirow{2}{*}{ Strains } & \multicolumn{4}{c}{ MBC/MIC } \\
\cline { 2 - 5 } & ECET & ECAT & FET & FAT \\
\hline S. aureus & 4 & $1^{*}$ & 4 & $2^{*}$ \\
M. luteus & - & - & 8 & $2^{*}$ \\
S. epidermidis & - & - & 512 & 16 \\
S. oralis & $1^{*}$ & $2^{*}$ & 8 & 8 \\
E. faecalis & - & - & - & - \\
Ps. aeruginosa & 128 & - & - & 16 \\
P. mirabilis & - & $2^{*}$ & 8 & - \\
P. vulgaris & & - & 4 & 8 \\
E. coli & - & - & 16 & 8 \\
C. albicans & - & - & $2^{*}$ & $2^{*}$ \\
\hline
\end{tabular}

ECET: ethanol bark extract, ECAT: acetylacetate bark extract, FET: ethanol leave extract, FAT: acetylacetate leave extract ; ${ }^{*}=$ with bactericidal effect.

Table 6. Bactericidal and bacterio-static effects of cashews bark and leave extracts on food isolated strains.

\begin{tabular}{lcccc}
\hline \multirow{2}{*}{ Strains } & \multicolumn{4}{c}{ MBC/MIC } \\
\cline { 2 - 5 } & ECET & ECAT & FET & FAT \\
\hline S. sciuri & 32 & 8 & 8 & 16 \\
S. aureus & - & 64 & 16 & 8 \\
S. simulans & - & - & $2^{*}$ & 4 \\
S. xylosus & - & - & 16 & 8 \\
S. cohnii & 8 & $2^{*}$ & 4 & $2^{*}$ \\
S. equorum & - & 8 & - & - \\
S. saprophyticus & 8 & $1^{*}$ & 4 & 4 \\
S. haemolyticus & - & 64 & 8 & 8 \\
S. lentus & - & 256 & 16 & 8 \\
\hline
\end{tabular}

ECET: ethanol bark extract, ECAT: acetylacetate bark extract, FET: ethanol leave extract, FAT: acetylacetate leave extract ; ${ }^{*}=$ with bactericidal effect.

extracts have inhibited the growth of yeast, Gram+ and Gram- bacteria. The same observations were made on the ethanol extract by Aiswarya et al. (2011). Indeed, these authors have shown that the cashews apple's ethanol extracts $(1 \mathrm{mg} / \mathrm{ml})$ inhibited the growth of Gram+ (Bacillus cereus) and Gram- (K. pneumoniae) bacteria. However, our results with aqueous extract contradict those reported by other authors in Nigeria during their work on the same kind of extract revealing that cashew leaf aqueous extract are able to inhibits, at $0.1 \mathrm{mg} / \mathrm{ml}$, the growth of B. cereus, Salmonella typhi and Shigella dysenteriae (Ifesan et al., 2013). The difference observed with ours work can be explained by the fact that the strains used are not the same and, additionally, strains are not from the same origin. Moreover, the $A$. occidentale leaves aqueous extract were known to make, at $200 \mathrm{mg} / \mathrm{ml}$, an inhibitory effect on the growth of many bacteria such as $S$. aureus, E. coli, P. aeruginosa, $S$. dysenteriae and Salmonella typhimurium (Omojasola and Awe, 2004). Comparing our results to those obtained by Omojasola and Awe (2004), the observed difference can be linked to the concentration $(20 \mathrm{mg} / \mathrm{ml})$ we used in our study that was tenfold lower than that reported by the latter authors.

Regarding the dichloromethane extract that has no effect on the strains, we can say that this solvent does not concentrate enough the compounds that can inhibit the microorganism's growth. Nevertheless during one of their studies, Ngari et al. (2013) showed that the Euclea divinorum root dichloromethane extracts can inhibits, at $200 \mathrm{mg} / \mathrm{ml}$, the growth of many bacteria among which $E$. coli, S. aureus and B. subtilis. Comparing the inactivity observed with dichloromethane extracts in the present study to those reported by Ngari et al. (2013), we can say that the difference may be not only be due to the fact that we did not use the same plant but also because the concentration they used $(200 \mathrm{mg} / \mathrm{ml})$ in their study was higher than ours $(20 \mathrm{mg} / \mathrm{ml})$.

Our study reveals that all the extracts were more active on food strain (in majority Gram+) than on reference strains (Figure 2). It was also observed that the extracts were more effective against Gram positive bacteria than Gram negative one. The results obtained in this study corroborate those of Agedah et al. (2010) when they showed that Gram positive bacteria are more sensitive to the cashew ethanol leaf extract than Gram- ones at the same concentration. These results can be explained by the fact that Gram positive bacteria are devoid of outer membrane in their cell walls. Thus, the outer membrane may be responsible of the difference observed in the sensitivity level between the Gram + and - in presence of the extract. Among all the tested extracts, we denote that leaves extracts (ethanol and acetyl acetate) are more effective than bark's. From this fact, we can speculate that the active antimicrobial agents may be more concentrated in the leaves than in barks. These results are in agreement with the assertion made by the traditional elders that, for the treatment of bacterial infections, the backs are mostly used than leaves (Chabi Sika et al., 2013). The antimicrobial activities observed may be explained by the presence of large chemical groups such as tannins, flavonoids, alkaloids, saponines, steroids or triterpenes (Amvam et al., 1998; Cowan, 1999; Kolodziej et al., 1999; Omojasola and Awe, 2004; Sujatha et al., 2011).

Considering the inhibition zone diameters, it was noticed that no significant difference was observed between the diameters of ethanol and acetyl acetate bark extracts regardless of duration ( 24 and $48 \mathrm{~h}$ ) on both reference and food isolated strains. These results 
corroborate those of Bolou et al. (2011) when they found no difference between the inhibition diameters of ethanol and acetyl acetate Terminalia glaucescens extracts on the growth of S. typhi. But, Arekemase et al. (2011) in their study denoted a significant difference between the inhibitions diameters at a concentration of $200 \mathrm{mg} / \mathrm{ml}$. The high concentration they use in their study and the difference of strains might be the reasons of this difference observed between our results and those of Arekemase et al. (2011).

Regarding the leaf extracts, the inhibition diameters of ethanol extract on the food-isolated strains were different $(p<0.05)$ at $24 \mathrm{~h}$ and highly different $(p<0.001)$ at $48 \mathrm{~h}$. The same observations of efficiency were made by Arekemase et al. (2011) by showing that the inhibition diameters of cashew leaf ethanol extract were significantly different among the studied strains. Besides, our results also show that the sensitivity of ethanol leaf extract was more efficient than the ethanol bark extract while acetyl acetate leaf extract was more efficient than the acetyl acetate bark extract (Figure 4). These results corroborate those of Hamid and Aiyelaagbe (2011) when they demonstrated, in vitro, that the alcohol extract of Alafiabarteri had a better inhibition effect on the growth of many bacterial (S. aureus, E. coli, $P$. aeruginosa and $C$. albicans) than the acetyl acetate extract. In the same way, Bolou et al. (2011) also demonstrated that the $T$. glaucescens acetyl acetate extract was more efficient than the ethanol extract on S. typhi. Taking into account the previous results from various studies, we can speculate that ethanol, as solvent, allow a better solubility of antimicrobial agent of the leaves than the barks; contrary to acetyl acetate in which the antimicrobial agent of barks are more soluble than that of leaves.

The MIC was variable depending on the strains and extracts (Tables 2 and 3). With the barks, the greater sensitivity was observed on S. xylosus (ethanol extract) and on S. equorum, S. saprophyticus and S. lentus (acetyl acetate extract) at the concentration of 0.078 $\mathrm{mg} / \mathrm{ml}$. With the leaves, at the concentration of 0.039 $\mathrm{mg} / \mathrm{ml}$, ethanol extracts inhibit the growth of $\mathrm{S}$. epidermidis. These concentrations were higher than those reported by Akash et al. (2009) when they proved that $S$. aureus and $B$. subtilis were more sensitive to the ethanol leaf extract of Anacardium occidentale with MIC = $15.62 \mu \mathrm{g} / \mathrm{ml}$. Nevertheless, our MIC values were lower than the $50 \mathrm{mg} / \mathrm{ml}$ reported by Arekemase et al. (2011). However, the greatest MIC was $0.625 \mathrm{mg} / \mathrm{ml}$ on all references strains and $2.5 \mathrm{mg} / \mathrm{ml}$ on S. simulans (among food-isolated strains) independently of the type of extracts. Akash et al. (2009), in one of their study, reported lower values $(31.25 \mu \mathrm{g} / \mathrm{ml})$ than ours; the difference observed may be explained by the divergent extraction methods and the different origins of strains used. Indeed, depending on the extraction methods, the antimicrobial agents extracted may have different concentrations. Thus, it appears that the extraction methods probably may have a major impact on the quantity of extracted antimicrobial agents.

The MBC were variable with regard not only to the strains but also to the type of extracts (Tables 3 and 4 ). With the bark extracts, the lower MBC was $0.078 \mathrm{mg} / \mathrm{ml}$ on S. saprophyticus with acetyl acetate extract and the greatest MBC was $20 \mathrm{mg} / \mathrm{ml}$ on $P$. aeruginosa with ethanol extract and on food-isolated $S$. aureus, $S$. haemolyticus and $S$. lentus with acetyl acetate extract. With the leaf extracts, the lowest MBC was $0.313 \mathrm{mg} / \mathrm{ml}$ on $C$. albicans with ethanol extract while the greatest MBC was $20 \mathrm{mg} / \mathrm{ml}$ on S. epidermidis, S. lentus with ethanol extract and $S$. sciuri with acetyl acetate extract. These results contrasted those of Quelemes et al. (2013) reporting a range of 6.75 to $27 \mu \mathrm{g} / \mathrm{ml}$ as MBC during an in vitro test of cashew gum on S. aureus, E. faecalis, E. coli, $K$. pneumoniae and $P$. aeruginosa.

The ratio parameters of the MIC and MBC shows that, according to the stains, leaf and bark extracts have both bactericidal and bacterio-statistical effect on reference and food-isolated strains (Tables 5 and 6). Thus, the acetyl acetate extracts have more bactericidal activity than ethanol extracts. Thus acetyl acetate leaf extract has a bactericidal effect on $S$. aureus, M. lentus and $C$. albicans regarding reference strains and on S. cohniu for food isolated strain. For the bark extracts, the bactericidal effect was observed on $S$. aureus, $S$. oralis and $P$. mirabilis regarding reference strains and on $S$. cohniu and S. saprophyticus for the food isolated strain. These results are similar to those reported by Dramane et al. (2010) which showed that the dichloromethane extract of Erythrina senegalensis has a bactericidal effect on many microorganisms (C. albicans, E. faecalis, S. epidermidis, $S$. aureus, $P$. mirabilis, E. coli and $P$. aeruginosa). The difference in bactericidal effect can be explained by the difference in the solvents used during the extraction and the different plants species used.

\section{Conclusion}

This study highlights the antibacterial activities of the cashew leaf and bark extracts. The activity of these extracts was remarkable on Staphylococcus food-isolated and reference strains in the study. The results show that the ethanol and acetyl acetate leaf extract were more efficient than the ethanol bark extract. Moreover good activity in the leaves than the bark was detected. These results partly justify the use of this plant by traditional healers in the treatment of certain diseases such as dysentery, diarrhea, skin diseases and urinary tract infections.

\section{Conflict of Interests}

The author(s) have not declared any conflict of interests. 


\section{ACKNOWLEDGEMENTS}

The authors thank the producers and others in the cashew sector during this study for their collaboration. This work was funded by the University of Abomey-Calavi through PROANAC project.

\section{REFERENCES}

Adebo IB, Doumbia I, Aka N, Dosso M,Guede-Guina F (2008). Evaluation de l'activité antibactérienne de Phyllanthus amarus (Euphorbiaceae) sur la croissance in vitro deMycobacteriumtuberculosis. Rev de Méd et de Pharm. 21:35-47.

Adejuwon AO, Agbaje EO, Idika N (2011).Antifungal and antibacterial activities of aqueous and methanolic root extracts of Carica papayalinn. Int. Res. J. Microbiol. 2:270-277.

Adesokan AA, Akanji MA, Yakubu MT(2007). Antibacterial potentials of aqueous extract of Enantiachlorantha stem bark. Afr. J. Biotechnol. 6 (22): 2502-2505.

Agedah CE, Bawo DDS, Nyananyo BL(2010). Identification of antimicrobial properties of cashew, Anacardium occidentale L. (Family Anacardiaceae). Int. J. Appl. Manage. Sci. 14(3)25-27.

Aiswarya G, Reza KH, Radhika G, Mohamed FS (2011). Study for antibacterial activity of cashew apple (Anacardium occidentale) extracts. Der Pharmacia Lettre 3(1): 193-200.

Akash PD, Vishal DJ, Arun B (2009). Antimicrobial Screening of Different Extract of Anacardium occidentale Linn.leaves. Int. J. Chem.Technol. Res. 1(4)856-858.

Akinwale TO (2000). Cashew apple juice: Its use in fortifying the nutritional quality of some tropical fruits. Eur. Food Res. Technol. 211:205-207.

Amvam ZPH, Biviti L, Tchoumbovgnang F, Menut C, Lamatv G,Bouchet $\mathrm{PH}$ (1998).Aromatic plants of Tropical Central Africa, Part Chemical composition and antifungal activity of thirteen essential oils from aromatic plants of Cameroon. Flavour Fragr. J. 13:107-114.

Anani K, Hudson JB, de Souza LC, Akpagana K, Towe GHN, Amason JT, Gbeassor M (2000).Investigation of medicinal plants of Togo for antiviral and antimicrobial activities. Pharm. Biol. 38 (1): 4045.

Arekemase MO, Oyeyiola GP, Aliyu MB (2011): Antibacterial Activity of Anacardium occidentaleon Some Enterotoxin Producing Bacteria. Int. J. Biol. 3(4)392-99.

Attien P, Sina H, Moussaoui W, Dadié T, Chabi Sika K, Djéni T, Bankole HS, Kotchni SO, Edoh V, Prévost G, Djè M, Baba-Moussa L (2013). Prevalence of antibiotic resistance of Staphylococcus strains isolated from meat products sold in Abidjan streets (Ivory coast): Afr. J. Microbiol. Res. 7: 3285-3293.

Badiaga M (2011). Etude ethnobotanique, phytochimique et activités biologiques de Nauclea latifoliasmith une plante médicinale africaine récoltée au Mali. Thèse de Doctorat unique à la Faculté des Sciences et Techniques (FAST), Université de Bamako, Mali. 183p

Biecke B (2004).Etnobotanishestudie van geneeskrachtigeplanten in Manigri en Igbére, Benin.Universiteit Gent., Bioingenieurinhetland, En BosBeheer, 420p.

Bocanegra-Garcia V, Camacho-Corona M, Ramirez-Cabrera M,GarzaGonzatez GR (2009).The bioactivity of plant extracts against representative bacterial pathogens of the lower respiratory tract. BMC Res. Notes 2: 95p

Bolou GEK, Attioua B, N'Guessan AC, Coulibaly A, N'Guessan JD, Djaman AJ (2011).Évaluation in vitro de l'activité antibactérienne des extraits de Terminalla glaucescensplanch. sur Salmonella typhi et Salmonella typhimurium. Bulletin de la Société Royale des Sciences de Liège 80: 772-790.

Cavalcante Ana AM, Rübensam G, Picada JN, Silva EG, Moreira FJC Henriques JAP (2003). Mutagenic evaluation, antioxidant potential and antimutagenic activity against hydrogen peroxide of cashew (Anacardium occidentale L.) apple juice and cajuina. Environ. Mol. Mut. 41:360-369
Chabi Sika K, Adoukonou-Sagbadja H, Ahoton LE, Adebo I, Adigoun FA, Saidou A, Kotchoni SO, Ahanchede A, Baba-Moussa L (2013). Indigenous knowledge and traditional management of cashew (Anacardium occidentale L.) genetic resources in Benin. J. Exp. Biol. Agric. Sci. 1(5):375-382

Cowan MM (1999). Plants products as anti-microbial activity.Clin Microbiol. Rev. 12(4):564-582.

Delarras C (1998). Microbiologie. 90 heures de travaux pratiques. Gaétan Morien Editeur. 169-178 ISBN: 291074907X 9782910749071.

Doughari JH, Pukuma MS, De N (2007).Antibacterial effects of Balanites aegyptiacaL. Drel. and Moringa oleifera Lam. on Salmonella typhi. Afr. J. Biotechnol. 6 (19):2212-2215.

Dramane S, Mamidou KW,Kagoyire K (2010).Evaluation des Activités Antimicrobiennes et Anti-Radicaux Libres de Quelques Taxons Bioactifs de Côte. Eur. J. Sci. Res. 40(2):307-317.

Gangoue PJ(2007). Caractérisation des bêta-lactamases et leur inhibition par les extraits de plantes médicinales. Thèse de doctorat des sciences en biochimie. Université de Liège. 1-4.

Guede-Guina F, Vangah-Mandah M, Bonga GM, de Souza C (1995). Activité antibactérienne d'un extrait végétale contre les germes opportunistes au cours du SIDA.Rev Méd Pharma. 9:13-19.

Hamid AA, Aiyelaagbe OO (2011). Preliminary Phytochemical, Antibacterial and Antifungal Properties of Alafia barteri Stem Grown in Nigeria. Eur. J. Med. Plants 1:26-32.

Ifesan BOT, Fashakin JF, Ebosele F,Oyerinde AS (2013).Antioxidant and Antimicrobial Properties of Selected Plant Leaves. Eur. J. Med. Plant 3(3):465-473.

Kolodziej H, Kayser O, Latte PK, Ferreira D (1999). Evaluation of the anti-microbial potency of tannins and related compound using the rnicrodilution broth method. Planta Med. 65: 444-446.

N'Guessan JD, Bidie AP, Lenta BN, Weniger B, Andre P, Guede-Guina F (2007).In vitro assays for bioactivity-guided isolation of antiSalmonella and antioxidant compounds in Thonningiasanginea flowers. Afr. J. Biotechnol. 6: 1685-1689.

Ngari FW, Gikonyo NK, Wanjau RN, Njagi EM (2013). Safety and Antimicrobial Properties of Eucleadivinorum Hiern, Chewing Sticks Used for Management of Oral Health in Nairobi County, Kenya. J. Pharm. Biomed. Sci. 3(3)1-8, 2013

Omojasola PF, Awe S (2004). The antibacterial activity of the leaf extracts of Anacardium occidentale and Gossypium hirsutun against some selected microorganisms. Biosci. Res. Commun. 60(1):25-58.

Quelemes PV, Araruna FB, de Faria BEF, Kuckelhaus SAS, da Silva DA, Mendonça RZ, Eiras C, Soares dos SMJ, Leite JRSA (2013).Development and Antibacterial Activity of Cashew GumBased Silver Nanoparticles.Int. J. Mol. Sci. 14:4969-4981.

WHO (2002). Stratégie de l'OMS pour la médecine Traditionnelle pour 2002-2005

Sanogo R, Diallo D, Diarra S, Ekoumou C, Bougoudogo F (2006). Activité antibactérienne et antalgique de deux recettes traditionnelles utilisées dans le traitement des infections urinaires et la cystite au Mali. Mali Médical 21:18-24.

Sofowora A (1984).Medicinal Plants and Traditional Medicine in Africa. John Wiley and Sons Ltd., New York, 1-20.

Sopkon N, Ouinsavi C (2002).Utilisations du Khayasenegalensisen médecine traditionnelle au Bénin. Rev. Méd. et Pharm. Afr. 16:9-19.

Sujatha S, Baby J, Antony ES (2011). Analysis of Phytochemical Composition and Bio-activity Against Clinical Pathogens of Essential Oil from Anacardium occidentale (L.).Int. J. Food Saf. 13:150-156.

Walsh C (2003). Antibiotics: actions, origins, resistance. Washington, D.C: ASM Press. $345 p$ 